Biol. Stud. 2021; 15(3): 61-72 • DOI: https://doi.org/10.30970/sbi.1503.657

www.http://publications.Inu.edu.ua/journals/index.php/biology

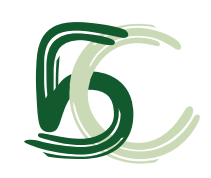

UDC: 598.574 .472 .574 .32

\title{
BIRDS DIVERSITY AND FAUNOGENETIC STRUCTURE OF AVIFAUNA IN FORESTS PARKS OF TWO MEGALOPOLISES (UKRAINE)
}

\author{
T. Shupova@ ${ }^{1}$, A. Chaplygina $\mathbb{1}^{2}$ \\ ${ }^{1}$ Institute for Evolutionary Ecology, NAS of Ukraine, 37 Lebedev St., Kyiv 03143, Ukraine \\ ${ }^{2}$ H.S. Skovoroda Kharkiv National Pedagogical University \\ 29 Alchevskyh St., Kharkiv 61002, Ukraine
}

Shupova, T., \& Chaplygina, A. (2021). Birds diversity and faunogenetic structure of avifauna in forests parks of two megalopolises (Ukraine). Studia Biologica, 15(3): 61-72 • DOI: https://doi. org/10.30970/sbi.1503.657

Background. In the 21st century, landscape transformation processes are underway in large cities, which affects the stability of wildlife habitats. Habitat transformations often reduce species richness due to a decrease in the population sizes of some species, and therefore, small in number and rare species are eliminated from bird communities. Rare species can have unique consortive relationships, which makes them particularly important for the long-term ecosystem functioning. A study of the avifauna of forest parks makes it possible to develop an algorithm for the coexistence of human and birds.

Methods. The number and distribution of birds were determined by route counting. The total length of the fixed route was $5.7 \mathrm{~km}$ in Kyiv and $3.5 \mathrm{~km}$ in Kharkiv. On each route, observations were carried out annually with three repetitions during the nesting period when the birds are most attached to their habitats (end of April-May-June). The average data for the total study period (2013-2017) were calculated for each city. For the average number, the standard deviation was calculated. An analysis of the faunogenetic structure of avifauna was carried out according to the method developed by V.P. Belik. A faunogenetic complex is a group of animal species associated by a common origin with ecosystems of a certain landscape-geographical zone. We also classified bird species into ecological groups according to the patterns of microhabitat choice. To compare the $\alpha$-diversity of bird in the forest-park zones of cities, a number of commonly accepted indices that express the correlation between the number and density of species were calculated:

\footnotetext{
() 2021 T. Shupova and A. Chaplygina. Published by the Ivan Franko National University of Lviv on behalf of Біологічні Студії Studia Biologica. This is an Open Access article distributed under the terms of the Creative Commons Attribution 4.0 License which permits unrestricted reuse, distribution, and reproduction in any medium, provided the original work is properly cited.
} 
1) Berger-Parker dominance index: $D_{\mathrm{BP}}=N_{i_{\max }} / \mathrm{N}$;

2) Shannon diversity index: $H^{\prime}=-\sum\left(P_{i} \times \operatorname{Ln} P_{i}\right)$;

3) Pielou evenness index: $E=H^{\prime} / \operatorname{LnS}$; where: $N_{i}$ - the number of each species; $N_{i_{\max }}$ - the maximum value of $N_{i} ; N=\sum N_{i}$ - the total number of all species (pairs $/ \mathrm{km}$ ); $P_{i}=N_{i} / N$ - the ratio of each species; $S$ - total number of the species.

Results. The study presents a comparative analysis of diversity and faunogenetic structure of avifauna in the forest park zones of Kyiv and Kharkiv, inhabited by 71 breeding species of birds that belong to 10 orders. In the eastern region, the proportion of birds of the boreal and the European forest-steppe complex decreases, but the share of the desert-mountain complex increases. The fauna of the European nemoral complex dominates (32.8 \% in Kyiv and $40.4 \%$ in Kharkiv). The basis of the communities are dendrophils: $83.6 \%(n=67)$ in Kyiv and $82.7 \%(n=52)$ in Kharkiv. The dominant species in all forest parks are the great tit (Parus major) and chaffinch (Fringilla coelebs).

Conclusions. The differences in the faunogenetic structure of bird communities are due to the proximity of model forest parks on the territory of Kyiv to the forest natural geographical zone, and on the territory of Kharkiv to the steppe, which leads in the eastern region to a decrease in the proportion of birds of the boreal and the European foreststeppe complex while the proportion of desert-mountain complex increases. Dendrophils predominate significantly, and the share of sclerophils and limnophils in total is less than $20 \%$ of the bird community in the forest parks of each city. As a consequence of the fragmentation of the Kiev forest park zone, the diversity of nesting birds communities in the forest-park zone of Kyiv is slightly lower than of Kharkiv, and the pressure of the dominant species is more significant.

Keywords: bird communities, faunogenetic structure, a-diversity, ecological groups, forest parks, Forest-steppe zone

\section{INTRODUCTION}

In the 21st century, landscape transformation processes are underway in large cities, which affects the stability of wildlife habitats. [13, 19, 21]. Habitat transformations often reduce species richness due to a decrease in the population sizes of some species $[7,15]$, and therefore, small in number and rare species are eliminated from bird communities [3]. Rare species can have unique consortive relationships, which makes them particularly important for the long-term ecosystem functioning. It is especially important to preserve the natural environment on the territory of megalopolises, where the mosaic landscape is saturated with buildings, which makes it, as an animal habitat, similar to those of different European countries [6,15]. A study of the avifauna of forest parks makes it possible to develop an algorithm for the coexistence of human and birds. We selected plots similar in biotopic structure and environmental conditions in the urban areas of the two largest cities of Ukraine with a population of more than 2 million people, which are situated in the same geographical zone.

The aim of this work was to study the faunogenetic structure of avifauna and the diversity of bird communities in the forest park zones of Ukrainian cities in the foreststeppe zone.

ISSN 1996-4536 (print) • ISSN 2311-0783 (on-line) • Біологічні Студії / Studia Biologica • 2021 • Том 15 / № 3 • С. 61-72 


\section{MATERIALS AND METHODS}

The data were collected during the nesting periods 2013-2017 in the model forest parks of two cities of Ukraine - Kharkiv and Kyiv. For the analysis, we used the average data for each of the cities for the indicated period. The coordinates of Kyiv center are

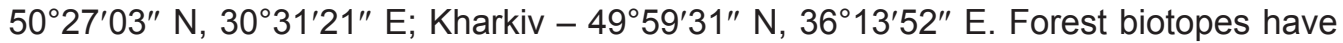
undergone changes, but forest parks include areas of natural forests with the predominance of Quercus robur L., Acer platanoides L., Carpinus betulus L., Alnus glutinosa Gaerth., Tilia cordata L. and with century-old trees on such transformed territories. All of the model sites have areas of natural biotopes, cultural phytocenoses, build-up territories, and are affected by a similar recreational anthropogenic load. The recreational regression of vegetation communities sometimes reaches stages $3-5[3,5]$. The main difference between the forest parks of Kyiv and Kharkiv is that the Kharkiv forest park is represented by a huge forest area of 2385 hectares, located on the periphery of the city, in which the biotopes adjacent to residential areas are cultivated and substantially transformed. In Kyiv, the forest park zone is fragmented into plots of various sizes (the largest $1052 \mathrm{ha}$ ), located both on the outskirts of the city and in the middle of a residential area.

The number and distribution of birds were determined by route counting [2]. The length of the transect was $0.8-1.0 \mathrm{~km}$ limited by the extent of a homogeneous biotope fragment; the width on both sides of the direction of movement was $50 \mathrm{~m}$; and the total length of the fixed route was $5.7 \mathrm{~km}$ in Kyiv and $3.5 \mathrm{~km}$ in Kharkiv. On each route, observations were carried out annually with three repetitions during the nesting period when the birds are most attached to their habitats (end of April-May-June). A singing male was counted as a nesting pair for passerine species [2]. The breeding status of species was determined by the behaviour or presence of a nest for non-Passeriformes species.

The average data for the total study period (2013-2017) were calculated for each city. For the average number, the standard deviation was calculated. The standard error is presented in the graphic illustration of the data. To compare the $\alpha$-diversity of birds in the forest park zones of cities, a number of commonly accepted indices that express the correlation between the number and density of species were calculated [17]:

1) Berger-Parker dominance index: $D_{\mathrm{BP}}=N_{i_{\max }} / N$;

2) Shannon diversity index: $\quad H^{\prime}=-\sum\left(P_{i} \times \operatorname{Ln} P_{i}\right)$;

3) Pielou evenness index: $\quad E=H^{\prime} / \mathrm{LnS}$;

where: $N_{i}$ - the number of each species, $N=\sum N_{i}$ - the total number of all species (pairs/ $\mathrm{km}) ; P_{i}=N_{i} / N$ - the ratio of each species; $N_{i \max }$ - the maximum value of $N_{i} ; S-$ total number of the species.

An analysis of the faunogenetic structure of avifauna was carried out according to the method developed by V.P. Belik. A faunogenetic complex is a group of animal species associated by a common origin with ecosystems of a certain landscape-geographical zone. These animals are maximally adapted to the conditions of this zone. The following types of avifauna are distinguished: 1 - Siberian, 2 - European, 3 - Chinese, 4-Nomadic, 5-Himalayan [1]. We used faunistic assemblages belonging to subordinate categories of classification in the analysis of avifauna: boreal, ancient nemoral, ancient forest-steppe, tropical, estuary, European forest-steppe, desert-mountain, sub-Mediterranean, the European nemoral complexes.

We also classified bird species into ecological groups according to the patterns of habitat choice [1]. The dendrophils are bird species that live on tree plantations. The 
limnophils include waterfowl and wading birds that live on or around water. The sclerophils are birds associated with vertically dissected relief (cracks in rocks, trees, stumps).

\section{RESULTS}

In the forest parks of the megalopolises of forest-steppe zone, 71 nesting species of birds of 10 orders were detected. In total, 49 bird species are common for the forest park zones in Kyiv and Kharkiv. In Kyiv forest parks, the relative number is $1.99( \pm 0.49)$ pairs $/ \mathrm{km}$ on average, in Kharkiv - $3.15( \pm 0.54)$ pairs $/ \mathrm{km}$. The dominant species in all forest parks are the great tit (Parus major) and chaffinch (Fringilla coelebs). According to Shannon, Berger-Parker, and Pielou indices, the $\alpha$-diversity of nesting bird communities in the forest park zone of Kyiv is slightly lower than of Kharkiv. In Kyiv, the pressure of the dominant species on common species is more significant. This may be a consequence of the fragmentation of the Kyiv forest park zone (Fig. 1).

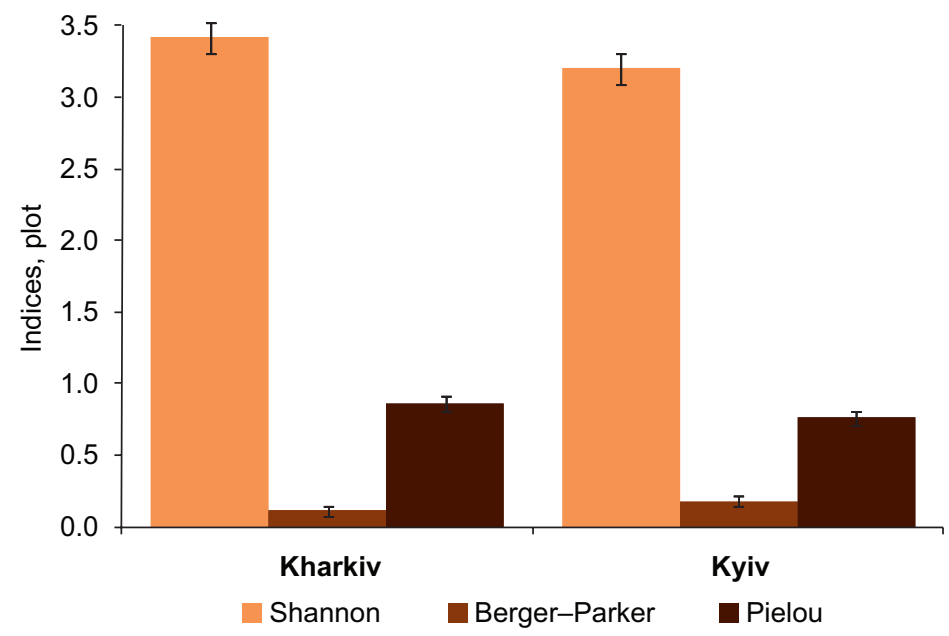

Fig. 1. $\alpha$-Diversity of birds in the forest park areas

Рис.1. $\alpha$-Різноманіття птахів лісопаркових зон

A study has shown that the avifauna of the forest parks in Kyiv is represented by 9 landscape-genetic faunal complexes, and in Kharkiv by 8 ones. This difference is due to the redshank (Tringa totanus) nesting in the forest park zone of Kyiv, the only representative of the estuary complex. The avifauna of the European nemoral complex dominates, and is represented in by 22 species in Kyiv forest parks, and by 21 in Kharkiv (32.8 \% and $40.4 \%$, respectively). The European nemoral complex of compared regions differs being complemented by one species - the common redstart (Phoenicurus phoenicurus) in the forest park zone of Kyiv (Table). For the ancient nemoral complex, significant differences were observed: 7 common species and 4 different ones, of which the goshawk (Accipiter gentilis) does not nest in the forest park zone in Kyiv, and the tawny owl (Strix aluco), wren (Troglodytes troglodytes), and long-tailed tit (Aegithalos caudatus) do not nest in the forest park zone in Kharkiv.

The greatest difference was revealed in the share of boreal birds. The differences in the abundance of boreal birds in the nesting bird communities of the studied forest parks are due to the absence of the mallard (Anas platyrhynchos), the green sandpiper

ISSN 1996-4536 (print) • ISSN 2311-0783 (on-line) • Біологічні Студії / Studia Biologica • 2021 • Том 15 / № 3 • C. 61-72 
(Tringa ochropus), the black woodpecker (Dryocopus martius), the grey shrike (Lanius excubitor), the black raven (Corvus corax), the red-breasted flycatcher (Ficedula parva), the coal tit (Parus ater) in the nesting areas of the forest parks in Kharkiv. Thus, in the communities of nesting birds in Kyiv forest parks, it is represented by 9 species $(13.4 \%)$, and in the bird communities in Kharkiv by 2 species (3.8\%). Differences were substantial in the proportions of birds of the European forest-steppe and desert-mountain complexes, whereby the former is more significantly represented in the nesting bird communities of the forest parks in Kyiv, and the latter in Kharkiv (Fig. 2). The European forest-steppe complex of birds in the forest parks of Kyiv is represented more widely due to the European reel (Serinus serinus), the garden bunting (Emberiza hortulana), lesser by the gray shrike (Lanius minor) and the nightjar (Caprimulgus europaeus). The ancient forest-steppe complex is small and represented in Kharkiv by the long-eared owl (Asio otus) and the magpie (Pica pica), and in Kyiv it is supplemented by the common buzzard (Buteo buteo) whose territorial behavior is annually recorded by us in the forest area of one of the model tracts.

The list of bird faunogenetic complexes

Список видів птахів за фауногенетичними комплексами

\begin{tabular}{|c|c|c|c|c|}
\hline No & Species & Kyiv & Kharkiv & Complex [1] \\
\hline 1 & 2 & 3 & 4 & 5 \\
\hline 1 & Anas platyrhynchos & + & - & bo \\
\hline 2 & Accipiter gentilis & - & + & an \\
\hline 3 & Accipiter nisus & + & + & an \\
\hline 4 & Buteo buteo & + & - & afs \\
\hline 5 & Falco tinnunculus & + & - & $\operatorname{tr}$ \\
\hline 6 & Tringa ochropus & + & - & bo \\
\hline 7 & Tringa totanus & + & - & es \\
\hline 8 & Columba palumbus & + & + & fs \\
\hline 9 & Columba livia & + & - & $\mathrm{dm}$ \\
\hline 10 & Streptopelia decaocto & + & + & $\operatorname{tr}$ \\
\hline 11 & Cuculus canorus & + & + & $\operatorname{tr}$ \\
\hline 12 & Asio otus & + & + & afs \\
\hline 13 & Strix aluco & + & - & an \\
\hline 14 & Caprimulgus europaeus & + & - & fs \\
\hline 15 & Alcedo atthis & - & + & $\operatorname{tr}$ \\
\hline 16 & Jynx torquilla & + & + & an \\
\hline 17 & Dendropicos spodocephalus & + & + & an \\
\hline 18 & Dryocopus martius & + & - & bo \\
\hline 19 & Dendrocopos major & + & + & an \\
\hline 20 & Dendrocopos syriacus & + & + & sm \\
\hline 21 & Leiopicus medius & + & + & $\mathrm{nm}$ \\
\hline
\end{tabular}

ISSN 1996-4536 (print) • ISSN 2311-0783 (on-line) • Біологічні Студії / Studia Biologica • 2021 • Том 15 / № 3 • С. 61-72 


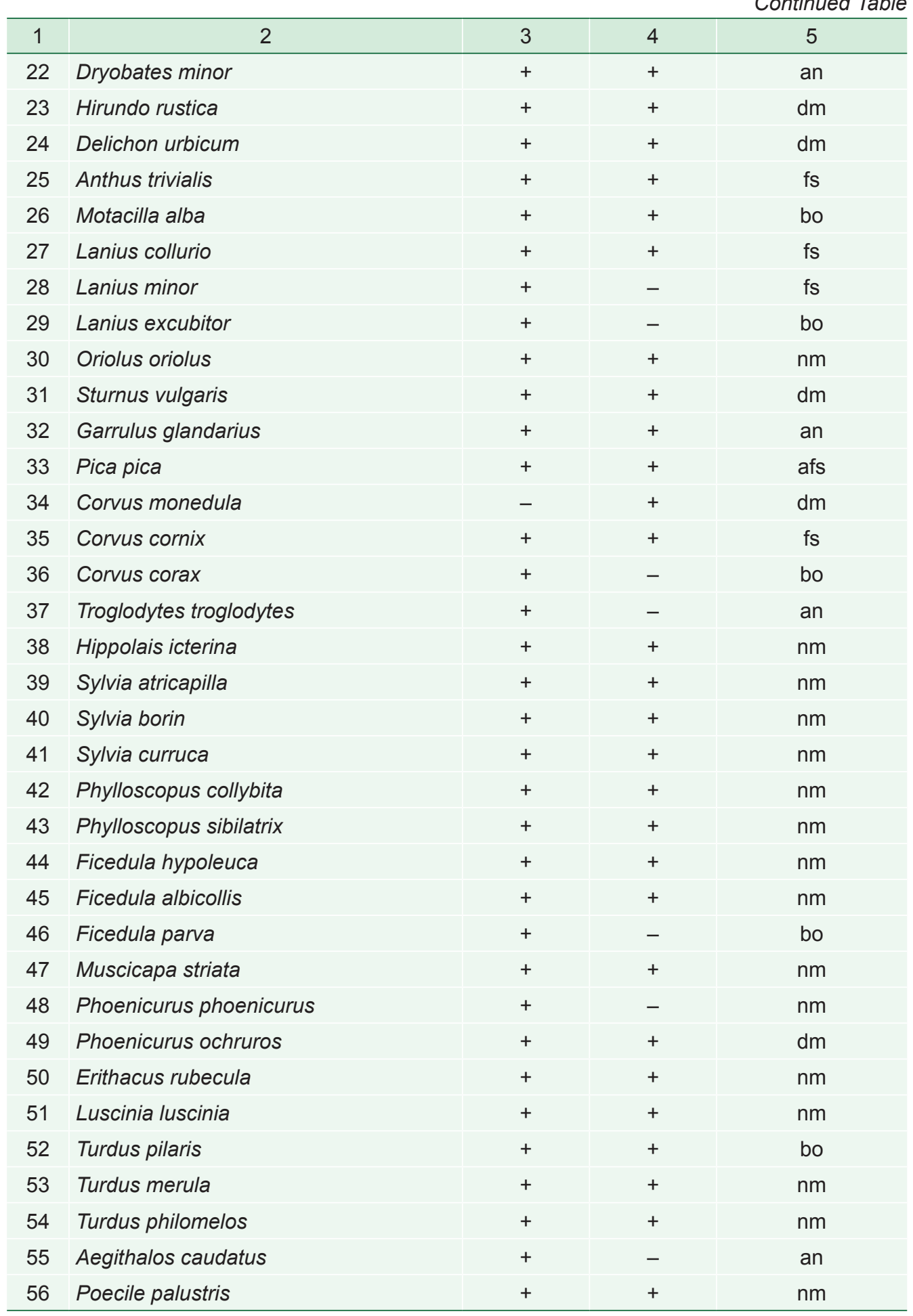

ISSN 1996-4536 (print) •ISSN 2311-0783 (on-line) • Біологічні Студії / Studia Biologica • 2021 • Том 15 / № 3 • С. 61-72 
End of the Table

\begin{tabular}{lllll}
\hline \multicolumn{1}{c}{2} & 3 & 4 & 5 \\
\hline 57 & Periparus ater & + & - & $\mathrm{bo}$ \\
58 & Cyanistes caeruleus & + & + & $\mathrm{nm}$ \\
59 & Parus major & + & + & $\mathrm{nm}$ \\
60 & Sitta europaea & + & + & $\mathrm{nm}$ \\
61 & Certhia familiaris & + & + & $\mathrm{nm}$ \\
62 & Passer domesticus & - & + & $\mathrm{dm}$ \\
63 & Passer montanus & + & + & $\mathrm{dm}$ \\
64 & Fringilla coelebs & + & + & $\mathrm{nm}$ \\
65 & Serinus serinus & + & - & $\mathrm{fs}$ \\
66 & Chloris chloris & + & + & $\mathrm{fs}$ \\
67 & Carduelis carduelis & + & + & $\mathrm{fs}$ \\
68 & Acanthis cannabina & + & + & $\mathrm{fs}$ \\
69 & Coccothraustes coccothraustes & + & + & $\mathrm{an}$ \\
70 & Emberiza citrinella & + & + & $\mathrm{fs}$ \\
71 & Emberiza hortulana & + & - & $\mathrm{fs}$ \\
\hline
\end{tabular}

Comments: bo - boreal; an - an ancient nemoral; afs - an ancient forest-steppe; tr - tropical; es - an estuary; fs - European forest-steppe; dm - a desert-mountain; sm - sub-Mediterranean; nm - the European nemoral complexes; + - species present at nesting

Примітки: bo - бореальний; an - древньо неморальний; afs - древньо лісостеповий; tr - тропічний; es - лиманний; fs - європейський лісостеповий; dm - пустеле-гірський; sm - середземноморський; nm - європейський неморальний комплекси; + - види, наявні на гніздуванні

Kyiv

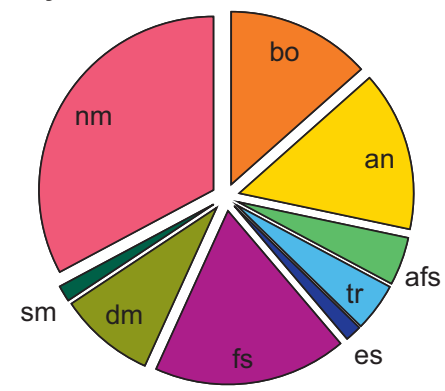

\section{Kharkiv}

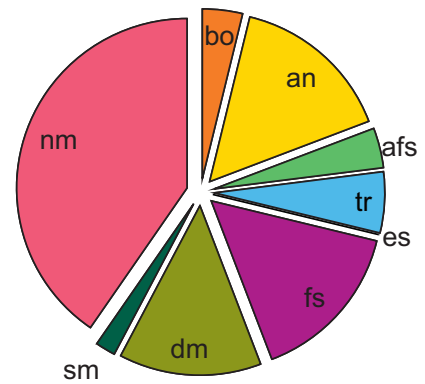

Fig. 2. Faunogenetic structure of bird communities in the forest parks of megalopolises (\%): bo - boreal; an - ancient nemoral; afs - ancient forest-steppe; tr - tropical; es - estuary; fs - European foreststeppe; $\mathrm{dm}$ - desert-mountain; sm - sub-Mediterranean; $\mathrm{nm}$ - the European nemoral complexes

Рис. 2. Фауногенетична структура угруповань птахів лісопарків мегаполісів (\%): bo - бореальний; an древньо неморальний; afs - древньо лісостеповий; tr - тропічний; es - лиманний; fs - європейський лісостеповий; dm - пустеле-гірський; sm - середземноморський; nm - європейський неморальний комплекси

The desert-mountain complex of birds is wider in Kharkiv due to the nesting of house sparrows (Passer domesticus) and jackdaws (Corvus monedula) in forest parks; 
in Kyiv, these species nest only in parks with a completely transformed landscape. In the tropical group common for both cities, the Eurasian collared dove (Streptopelia decaocto), the cuckoo (Cuculus canorus) are present. In Kyiv, the species composition of the group is supplemented by the common kestrel (Falco tinnunculus), in Kharkiv by the common kingfisher (Alcedo atthis). The sub-Mediterranean complex is represented by the Syrian woodpecker (Dendrocopos syriacus).

The basis of bird communities is dendrophils: $83.60 \%(n=67)$ of the avifauna in the Kyiv forest parks and $82.70 \%(n=52)$ in Kharkiv. The share of sclerophils $(13.50 \%)$ is higher in Kharkiv, and limnophils (5.97\%) - in Kyiv.

\section{DISCUSSION}

Large-scale changes in regional faunas (caused inter alia by human activities) are now observed practically throughout the Palearctic, therefore, the importance of elucidating the patterns of faunogenesis and predicting its development is constantly increasing $[1,8,14,16]$. In this regard, we also pay attention to the types of faunas that form communities of nesting birds in the forest parks of megacities of the forest-steppe zone in Ukraine. Belonging of the forest parks to one natural-geographical zone determines the similarity of the studied bird communities. The similarity of the genetic faunistic complexes of the avifauna of the western and eastern areas of the study is also due to the lack of oak regeneration in the forests of Kyiv. The dependence of the diversity of bird communities on the characteristics of the standing trees and the mosaic habitats was shown by many researchers $[9,12,20,22]$. The analysis of scientific literature showed that the change in the species composition of forest-forming plants can influence the birds' choice of the nesting biotope [11,18], and therefore the structure of the nesting bird community and its species richness are gradually transforming [3, 4, 12]. Thus, we believe that the homogenization of the European avifauna is caused not only by the direct urbanization of the birds' habitat [6], but also indirectly through the expansion of human impact on natural ecosystems that are in the immediate vicinity to the urbanized biotopes. Unfortunately, the types of fauna in themselves allow for analyzing mainly the avifauna of large regions [1]. To identify differences in the adaptation of the avifauna of Kyiv and Kharkiv to the conditions of the forest park zones, we compared the distribution of bird species composition in ecological complexes, depending on the birds' belonging to certain types of habitats. The avifauna of the forest parks is represented by three ecological complexes, where dendrophils predominate significantly, and the share of sclerophils and limnophils in total is less than $20 \%$ of the bird community in the forest parks of each city. This picture is also due to the environmental characteristics of one natural geographic area.

\section{CONCLUSIONS}

The differences in the faunogenetic structure of bird communities are due to the proximity of model forest parks on the territory of Kyiv to the forest natural geographical zone, and on the territory of Kharkiv to the steppe. This leads to a decrease in the proportion of birds of the boreal and the European forest-steppe complex in the eastern region, while the proportion of desert-mountain complex increases. Dendrophils predominate significantly, and the share of sclerophils and limnophils in total is less than $20 \%$ of the bird community in the forest parks of each city. As a consequence of the

ISSN 1996-4536 (print) • ISSN 2311-0783 (on-line) • Біологічні Студії / Studia Biologica • 2021 • Том 15 / № 3 • С. 61-72 
fragmentation of the Kyiv forest park zone, the diversity of nesting bird communities in the forest-park zone of Kyiv is slightly lower than of Kharkiv, and the pressure of the dominant species is more significant.

\section{COMPLIANCE WITH ETHICAL STANDARDS:}

Conflict of Interest: The authors made an equal contribution during the research in the analysis of the results and in the writing of the text of the manuscript, and have no conflicts of interest.

Animal Rights: This research does not contain animal experiments; the study was carried out using visual and acoustic observation methods.

\section{ACKNOWLEDGEMENTS}

The authors express heartfelt appreciation to Doctor of Biological Sciences, Professor Viktor Belik for consultancy and assistance in the preparation of this paper.

1. Belik, V.P. (2006). Faunogenetic structure of the Palearctic avifauna. Entomological Review, 86(S1), S15-S31.

Crossref • Google Scholar

2. Bibby, C.J., Burgess, N.D., Hill, D.A., \& Mustoe, S. (2000). Bird census techniques, 2nd edn. Academic Press, London. Google Scholar

3. Blinkova, O., \& Shupova, T. (2018). Bird communities and vegetation composition in natural and semi-natural forests of megalopolis: correlations and comparisons of diversity indices (Kyiv city, Ukraine). Ekológia (Bratislava), 37(3), 259-288.

Crossref • Google Scholar

4. Blinkova, O.I., Shupova, T.V., \& Raichuk, L.A. (2020). Syn-Ecological Connections and Comparison of A-Diversity Indices of Plant and Bird Communities on Cultivated Coenosises. Journal of Landscape Ecology, 13(2), 62-78.

Crossref • Google Scholar

5. Chaplygina, A.B. (2015). Ecofaunistic analysis and breeding success of dendrophilous on transformed territories of North-Eastern Ukraine. Studia Biologica, 9(2), 133-146. [In Ukrainian] Crossref • Google Scholar

6. Croci, S., Buter, A., \& Clergeau, P. (2008). Does urbanization filter birds on the basis of their biological traits? The Condor, 110(2): 223-240.

Crossref $\bullet$ Google Scholar

7. Evans, K.L. (2010). Individual species and urbanisation. Urban Ecology (ed. K.J. Gaston), pp. 53- 87. Cambridge University Press, Cambridge.

Crossref • Google Scholar

8. Díaz, M., Parra, A., \& Gallardo, C. (2011). Serins respond to anthropogenic noise by increasing vocal activity. Behavioral Ecology, 22(2), 332-336.

Crossref • Google Scholar

9. Domokos, E., \& Domokos, J. (2016). Bird communities of different woody vegetation types from the Niraj Valley, Romania. Turkish Journal of Zoology, 40: 734-742.

Crossref • Google Scholar

10. Gabbe, A.P., Robinson, S.K., \& Brawn, J.D. (2002). Tree-species preferences of foraging insectivorous birds: implications for floodplain forest restoration. Conservation Biology, 16(2), 462-470.

Crossref $\bullet$ Google Scholar

ISSN 1996-4536 (print) • ISSN 2311-0783 (on-line) • Біологічні Студії / Studia Biologica • 2021 • Том 15 / № 3 • С. 61-72 
11. Gil-Tena, A., Saura, S., \& Brotons, L. (2007). Effects of forest composition and structure on bird species richness in a Mediterranean context: Implications for forest ecosystem management. Forest Ecology and Management, 242(2-3), 470-476.

Crossref $\bullet$ Google Scholar

12. Graham, C.T., Wilson, M.W., Gittings, T., Kelly, T.C., Irwin, S., Sweeney, O.F.M., \& O'Halloran, J. (2014). Factors affecting the bird diversity of planted and semi-natural oak forests in Ireland. Bird Study, 61(3), 309-320.

Crossref $\bullet$ Google Scholar

13. Grimm, N.B., Faeth, S.H., Golubiewski, N.E., Redman, C.L., Wu, J., Bai, X., \& Briggs, J.M. (2008). Global change and the ecology of cities. Science, 319(5864), 756-760.

Crossref $\bullet$ PubMed $\bullet$ Google Scholar

14. Güneralp, B., \& Seto, K.C. (2013). Futures of global urban expansion: uncertainties and implications for biodiversity conservation. Environmental Research Letters, 8(1), 014025. Crossref • Google Scholar

15. Kooiker, G. (2007). Vogelmonitoring in Osnabrück: Ergebnisse langjähriger Bestandserfassungen (1986 bis 2006) im innerstädtischen Siedlungsraum. Vogelkundliche Berichte aus Niedersachsen, 39: 61-75.

Google Scholar

16. Lawlor, K., \& Meng, Y. (2019). The changing trend in songbirds' abundance, variety and physical condition in Connecticut's forestry habitat. Forestry Studies, 70(1), 17-30.

Crossref $\bullet$ Google Scholar

17. Magurran, E. (1988). Ecological diversity and its measurement. Princeton University Press, Princeton NJ.

Crossref $\bullet$ Google Scholar

18. Sweeney, O.F.M., Wilson, M.W., Irwin, S., Kelly, T.C., \& O'Halloran, J. (2010). Are bird density, species richness and community structure similar between native woodlands and non-native plantations in an area with a generalist bird fauna? Biodiversity and Conservation, 19(8), 2329-2342.

Crossref $\bullet$ Google Scholar

19. Møller, A.P., Díaz, M., Flensted-Jensen, E., Grim, T., Ibáñez-Álamo, J.D., Jokimäki, J., Mänd, R., Markó, G., \& Tryjanowski, P. (2015). Urbanized birds have superior establishment success in novel environments. Oecologia, 178(3), 943-950.

Crossref $\bullet$ PubMed $\bullet$ Google Scholar

20. Moreno-Rueda, G., \& Pizarro, M. (2008). Relative influence of habitat heterogeneity, climate, human disturbance, and spatial structure on vertebrate species richness in Spain. Ecological Research, 24(2), 335-344.

Crossref $\bullet$ Google Scholar

21. Palomino, D., \& Carrascal, L.M. (2007). Threshold distances to nearby cities and roads influence the bird community of a mosaic landscape. Biological Conservation, 140(1-2), 100-109.

Crossref $\bullet$ Google Scholar

22. Tews, J., Brose, U., Grimm, V., Tielbörger, K., Wichmann, M.C., Schwager, M., \& Jeltsch, F. (2003). Animal species diversity driven by habitat heterogeneity/diversity: the importance of keystone structures. Journal of Biogeography, 31(1), 79-92.

Crossref $\bullet$ Google Scholar

ISSN 1996-4536 (print) • ISSN 2311-0783 (on-line) • Біологічні Студії / Studia Biologica • 2021 • Том 15 / № 3 • С. 61-72 


\title{
РІЗНОМАНІТТЯ ПТАХІВ I ФАУНОГЕНЕТИЧНА СТРУКТУРА АВІФАУНИ ЛІСОПАРКОВОЇ ЗОНИ ДВОХ МЕГАПОЛІСІВ (УКРАЇНА)
}

\author{
Т. Шупова", А. Чаплигіна² \\ ${ }^{1}$ Державна установа "Інститут еволюційної екології НАН України" \\ вул. Лебедєва, 37, Київ 03143, Україна \\ ${ }^{2}$ Харківський національний педагогічний університет імені Г. С. Сковороди \\ вул. Алчевських, 29, Харків 61002, Україна
}

Вступ. У XXI ст. у великих містах триває трансформація ландшафтів, яка знищує середовище існування тварин, призводить до зменшення видового багатства внаслідок падіння чисельності популяцій деяких видів, унаслідок чого нечисленні види зникають. Рідкісні види можуть мати унікальні консортивні зв'язки, що підкреслює їхню значущість задля довготривалого фрункціонування екосистеми. Вивчення орнітофауни лісопарків дає змогу розробити алгоритм співіснування людини й аборигенних видів птахів. Для дослідження ми обрали близькі за структурою біотопів та за умовами середовища існування ділянки у межах міста двох мегаполісів із населенням більше 2 млн осіб та розташованих на території однієї природно-географрічної зони (Лісостепу).

Методи. Видовий склад, чисельність і розподіл птахів досліджували методом обліку на маршрутах. Загальна довжина фріксованого маршруту становила близько 5,7 км у Києві та 3,5 км у Харкові. На кожному маршруті спостереження проводили щороку тричі на період гніздування (кінець квітня - травень - червень). Для кожного міста розраховували середні дані чисельності птахів за весь період досліджень (2013-2017). Для середньої чисельності обчислювали стандартне відхилення. Аналіз фрауногенетичної структури проводили за методикою В.П. Бєліка. Фауногенетичний комплекс - це група тварин, яка має спільне походження та пов'язана з екосистемами конкретної природно-географічної зони. Також ми порівнювали екологічну структуру авіфрауни відповідно до закономірностей вибору птахами середовища існування.

Для порівняння а-різноманітності птахів у лісопаркових зонах Києва та Харкова було розраховано низку загальноприйнятих індексів:
1) індекс домінування Берґера-Паркера:
$D_{\mathrm{BP}}=N_{i_{\text {max }}} / N$;
2) індекс різноманіття Шеннона:
$H^{\prime}=-\sum\left(P_{i} \times \operatorname{Ln} P_{i}\right)$;
3) індекс рівномірності розподілу видів Пієлу: $E=H^{\prime} / \mathrm{LnS}$;

де: $N_{i}$ - щільність кожного виду, $N_{i_{\max }}$ - максимальний показник щільності, $N=\sum N_{i}-$ загальна щільність усіх видів (пар/км); $P_{i}=N_{i} / N$ - питома рясність виду в угрупованні; S - загальна кількість видів.

Результати досліджень. Надано порівняльний аналіз $\alpha$-різноманіття і структури орнітофауни лісопаркових зон Києва і Харкова, де відмічено 71 вид птахів 10 рядів. У видовому складі лісопарків більш східного регіону України частка птахів бореального та європейського лісостепового комплексів зменшується, натомість збільшується частка птахів пустеле-гірського комплексу. Загалом переважає фрауна європейського неморального комплексу (32,8 \% у Києві; 40,4 \% у Харкові). Основу угруповань становлять дендрофріли: 83,6 \% ( $n=67)$ у Києві та 82,7 \% (n=52) у Харкові. Домінують у всіх лісопарках синиця велика (Parus major) і зяблик (Fringilla coelebs).

ISSN 1996-4536 (print) • ISSN 2311-0783 (on-line) • Біологічні Студії / Studia Biologica • 2021 • Том 15 / № 3 • С. 61-72 
Висновки. Відмінності фауногенетичної структури угруповань птахів обумовлені близькістю модельних лісопарків Києва до лісової зони, а лісопарку Харкова до степової. Наслідком впливу сусідньої природно-географрічної зони виявлено зменшення при наближенні до Степу частки видів бореального та європейського лісостепового комплексів, і збільшення частки пустеле-гірського комплексу у видовому складі угруповань птахів. В обох регіонах в екологічній структурі переважають дендрофіли, а частка склерофрілів і лімнофілів загалом у лісопарках кожного міста становить менше 20 \%. Унаслідок фррагментації Київської лісопаркової зони різноманіття угруповань птахів тут трохи вище, ніж у Харківській, а тиск домінуючих видів більш виражений.

Ключові слова: угруповання птахів, фауногенетична структура, а-різноманіття, екологічні групи, лісопарки, лісостепова зона 